\title{
Adhesion and Initial Colonization of Streptococcus mutans is Influenced by Time and Composition of Different Composites
}

\author{
La Adhesión y la Colonización Inicial de Streptococcus mutans están Asociadas al \\ Tiempo y la Composición de Diferentes Compuestos
}

Raquel A. B. Silva1; Paulo Nelson-Filho'; Katharina M. H. De Oliveira'; Priscilla C. Romualdo'; Patrícia Gatón-Hernandez'; Carolina P. Aires ${ }^{3}$ \& Lea A. B. Silva1

SILVA, R. A. B.; NELSON-FILHO, P.; DE OLIVEIRA, K. M. H.; ROMUALDO, P. C.; GATÓN-HERNANDEZ, P.; AIRES, C. P. \& SILVA, L. A. B. Adhesion and initial colonization of streptococcus mutans is influenced by time and composition of different composites. Int. J. Odontostomat., 12(4):395-400, 2018.

ABSTRACT: The aim of this study was to evaluate the adhesion and initial colonization of $S$. mutans on the surface of novel composite resins during three experimental periods. Biofilms were formed on specimens of Enamel Plus HRI (Hri), FiltekTM Silorane (Si), Tetric EvoCeram ${ }^{\circledR}$ Bulk Fill (Te), KaloreTM (K), and FiltekTM Z250 (Z) ( $\mathrm{n}=4 /$ experimental period). After 4, 8 and 24 hours, the specimens were assessed for bacterial colony forming unit (CFU/mm²) levels and scanned by electron microscopy. All material surfaces showed a similar susceptibility to bacterial adhesion at 4 hours ( $p>0.05)$. The amount of microorganisms in the formed biofilms increased at 8 hours for all groups $(p<0.05)$ and decreased at 24 hours only for Te and $Z$ groups $(p<0.05)$. After $24 \mathrm{~h}$, the $\mathrm{K}$ group showed higher microorganism counts compared to the other groups. All composite resins evaluated were susceptible to adhesion by streptococci. However, bacteria attachment was not sufficient to maintain S. mutans colonization on Tetric EvoCeram ${ }^{\circledR}$ Bulk Fill and FiltekTM Z250 composites. Composite $\mathrm{K}$ presented the highest mean values for bacterial adhesion. Also, it was observed that the composition of resins could interfere with colonization mechanisms.

KEY WORDS: composite resins; biofilm, streptococcus mutans, electron microscopy.

\section{INTRODUCTION}

Composite resins are esthetic materials widely used in restorative dentistry. Over the past decades, there has been continuous development in attempts to improve the properties of composite resins. Most of these resins are methacrylate-based composites (Weinmann et al., 2005). However, methacrylatebased composites' increased polymerization shrinkage correspond to a critical disadvantage as this could lead to marginal gaps between the material and the cavity walls (Goldberg, 2008), resulting in biofilm accumulation and occurrence of caries adjacent to the restoration (Buergers et al., 2009).

In order to overcome this limitation of methacrylate-based composites, a composite resin that exhibits "silorane" (association of siloxanes and oxiranes) in its composition was developed (Gao et al., 2012; Gregor et al., 2013). Another monomer developed in an attempt to reduce polymerization shrinkage is the high molecular weight urethane dimethacrylate-based monomer named DX-511. This monomer can be found in the KaloreTM composite (Boaro et al., 2013). However, there are no studies in the literature evaluating the bacterial adhesion of this type of composite resin to date. Thus, considering that microorganisms have a higher affinity for resin composites in comparison to the enamel and other restorative materials, such as ceramic and metals

\footnotetext{
1 Department of Pediatric Dentistry. School of Dentistry of Ribeirão Preto - University of São Paulo. Ribeirão Preto, SP, Brazil.

${ }^{2}$ Department of Integrated Pediatric Dentistry. School of Dentistry, University of Barcelona. Barcelona, Spain.

${ }^{3}$ Department of Physics and Chemistry. Faculty of Pharmaceutical Sciences of Ribeirão Preto, University of São Paulo, São Paulo, Brazil.
} 
(Delaviz et al., 2014), studies involving microorganisms' attachment to resins surfaces are relevant.

Caries development at the restoration margins is a considerable reason for composite restoration failure (Bernardo et al., 2007). Recurrent decay is linked to failure of the bond between the tooth and composite and to increased levels of the cariogenic bacterium, Streptococcus mutans, localized around the perimeter of these materials (Filoche et al., 2010; Spencer et al., 2014). Thus, considering that dental caries is preceded by the attachment of indigenous oralbacteria, evaluation of bacterial adhesion or colonization on resin-based composites could be highly desirable to guide material selection.

In this sense, Streptococcus mutans plays an important role in the pathogenesis of the caries disease (Bowen, 1999). Its role as a pioneer organism in biofilm formation supports the subsequent colonization of the surface by other bacterial species (Spencer et al.), providing a cascade of events leading to the demineralization process. In order to prevent bacterial adhesion and, consequently, control dental caries, some authors have studied chemical modifications of resin composition (Ferracane, 2011). Despite improved physical and mechanical properties, there is no consensus in the literature regarding the influence of the surface properties on bacterial adhesion (Buergers et al.; Claro-Pereira et al., 2011).

Thus, in order to predict biological adhesion of resin-based materials, the aim of this study was to evaluate susceptibility of dental composites to $S$. mutans adhesion and initial biofilm formation. The null hypothesis was that there would be no differences between the dental restorative materials studied regarding the adherence susceptibility of cariogenic S. mutans.

\section{MATERIAL AND METHOD}

Experimental design. Biofilms were formed on specimens of composite resin and were collected at 4,8 , and 24 hours ( $n=4$ /experimental period). After the formation of biofilm during the experimental periods, the specimens were assessed for bacterial colony forming unit $\left(\mathrm{CFU} / \mathrm{mm}^{2}\right)$ levels $(n=3$ /experimental period) and analyzed by scanning electron microscopy ( $n=1$ /experimental period).
Preparation of specimens. Five different micro- or nanohybrid composites were selected for the study $(n=4)$. Table I shows the materials evaluated and their manufacturers. Cylindrical specimens $(3.0 \mathrm{~mm}$ in diameter and $2.0 \mathrm{~mm}$ th ickness) of the test materials were prepared according to the manufacturers' specifications, using a prefabricated circular Teflon mold. After the insertion of composites at the upper face, a cellulose acetate strip was used to provide composite regularization. The disk-shape specimens were lightcured (SDI Radii plus, SDI, Bayswater, Australia; 1500 $\mathrm{mW} / \mathrm{cm}^{2}$ ) for $40 \mathrm{~s}$ and finally removed from the plate. Disk samples were measured (surface area of $32.85 \pm$ $0.45 \mathrm{~cm}^{2}$ ) and sterilized by gamma radiation for 30 minutes (RAD Source RS-2000, 160kV, 25mA, 130Gy).

Initial biofilms and microbiological analysis. Initial biofilms of $S$. mutans UA159 were formed on disk surfaces in batch cultures for 4,8 , or 24 hours $(n=3)$. The biofilms were grown in ultrafiltered $(10 \mathrm{kDa}$ molecular-weight cut-off) buffered tryptone yeast-extract broth containing $1 \%(\mathrm{w} / \mathrm{v})$ sucrose. At selected time points (4-, 8- and 24-hour-old initial biofilm), the disks were dip-rinsed in sterile saline solution (to remove excess culture medium or bacteria that was not attached) and transferred to tubes containing $0.9 \% \mathrm{NaCl}$. The biofilms were removed by sonication using $15 \mathrm{~s}$ pulses at an output of $20 \%$ amplitude (Fischer Scientific, CL334 ) in order to homogenize biofilms for microbiological analysis.

An aliquot of $100 \mu \mathrm{L}$ of the sonicated biofilm suspension was diluted in $0.9 \% \mathrm{NaCl}$ and serial dilutions were inoculated in duplicate by the drop-counting technique in $\mathrm{BHI}$ (Brain Heart Infusion) agar plates. The plates were incubated in $10 \% \mathrm{CO}_{2}$ at $37 \mathrm{oC}$ for 24 hours. The colony-forming units (CFU) were counted and the results expressed in $\mathrm{CFU} / \mathrm{mm}^{2}$.

Scanning Electron Microscopy (SEM). The structure of the biofilms was qualitatively examined by SEM $(n=1)$. Briefly, samples were fixed in modified Karnovsky's solution ( $2.5 \%$ glutaraldehyde, $4 \%$ paraformaldehyde, in $0.1 \mathrm{M}$ sodium cacodylate, $\mathrm{pH}=7.2-7.4$ ) and post-fixed in $2 \%$ osmium tetroxide solution for 2 hours, washed, and subjected to dehydration in increasing concentrations of alcohol (30\%, $50 \%, 70 \%, 80 \%, 90$ $\%$, $95 \%$, and $100 \%$ ). Next, samples were dried in a Critical Point Dryer (BAL-TEC) with liquid $\mathrm{CO}_{2}$, mounted on a copper support, and metallized with gold-pale in DENTON VACCUM DESK II20. The electron micrographs were obtained using a scanning electron microscope (JEOL JSM-5410, USA), $3.5 \mathrm{~nm}$, at $30 \mathrm{kV}$. 
SILVA, R. A. B.; NELSON-FILHO, P.; DE OLIVEIRA, K. M. H.; ROMUALDO, P. C.; GATÓN-HERNANDEZ, P.; AIRES, C. P. \& SILVA, L. A. B. Adhesion and initial colonization of streptococcus mutans is influenced by time and composition of different composites. Int. J. Odontostomat., 12(4):395-400, 2018.

Table I. Trade mark, manufacturer, and composition of the composite resins evaluated in the study.

\begin{tabular}{|c|c|c|}
\hline Composite Resins & Manufacturer & Composition \\
\hline $\begin{array}{l}\text { Enamel Plus HRI } \\
\text { (Hri) }\end{array}$ & Micerium SpA & $\begin{array}{l}\text { - Matrix: Methacrylate-bas ed chemistry (Bis-GMA, UDMA, Butanediol dimethacrylate) } \\
\text { - Nano-hybrid composite } \\
\text { - Content of filler ( } 80 \% \text { weight): Glass filler with high refractive index and surface } \\
\text { treated nano zirconium oxide partides. }\end{array}$ \\
\hline $\begin{array}{l}\text { Filtek }^{\mathrm{TM}} \text { Silorane } \\
(\mathrm{Si})\end{array}$ & 3M ESPE & $\begin{array}{l}\text { - Matrix: Silorane resin-based chemistry } \\
\text { - Micro-hyb rid composite } \\
\text { - Content of filler ( } 76 \% \text { weight): Quartz particles and radiopaque Yttrium Fluoride }\end{array}$ \\
\hline Tetric EvoCeram® & Ivoclar & - Matrix: Methacrylate-bas ed chemistry (Bis-GMA, Bis-EMA and UDMA) \\
\hline Bulk Fill (Te) & Vivadent & $\begin{array}{l}\text { - Nano-hybrid composite } \\
\text { - Content of filler ( } 80 \% \text { by weight): barium aluminum silicate glass, ytterbium fluoride } \\
\text { and spherical mixed oxide }\end{array}$ \\
\hline Kalore $\mathrm{T}^{\mathrm{M}}(\mathrm{K})$ & GC Dental & - Matrix: UDMA, dimethacrylate co-monomers and DX-511 monomer \\
\hline Filtek $^{\mathrm{TM}} \mathrm{Z250}(\mathrm{Z})$ & Products & $\begin{array}{l}\text { - Nano-hybrid composite } \\
\text { - Content of filler ( } 82 \% \text { weight): Fluoroaluminosilicate glass, High Density Radiopaque } \\
\text { (HDR) prepolymenzed fillers and silicon dioxide } \\
\text { - Matrix: Methacrylate-bas ed chemistry (Bis-EMA, UDMA, Bis-GMA) } \\
\text { - Micro-hybrid composite } \\
\text { - Content of filler ( } 82 \% \text { by weight): Zrconia/Silica }\end{array}$ \\
\hline
\end{tabular}

Statistical analysis. The analysis were performed with SAS software (SAS Institute Inc. The SAS System, release 9.3, 2012, SAS Institute Inc., Cary, NC, USA) with a significance level of 0.05 . Data were analyzed by analysis of variance (ANOVA) followed by HolmTukey test.

\section{RESULTS}

There were performed two statistical comparisons. First, when analyzed the influence of time on the composites behavior, all composites showed means lower than $1 \times 10^{4} \mathrm{CFU} / \mathrm{mm}^{2}$ at $4 \mathrm{~h}$. From 4 to 8 hours, all composites showed significantly increased values of $\mathrm{CFU} / \mathrm{mm}^{2}(\mathrm{p}<0.05)$. Finally, at 24 hours, two behaviors were observed: the composites Hri, $\mathrm{K}$, and Si did not exhibit significant variation in means of CFUs $(p>0.05)$, while $\mathrm{Te}$ and $Z$ exhibited a significant reduction in means of CFUs $(p<0.05)$. Figure 1 illustrates the time-dependent influence on biofilm formation on the composites surfaces represented by uppercase letters in Table II.

Once completed the analysis of the influence of time on the composites behavior, there were performed the comparisons between the composites, independently, in each time, as highlighted in lowercase letters in Table II. At 4 hours, there was no statistical difference between the composites. At 8 and $24 \mathrm{~h}$, the $\mathrm{K}$ composite presented the highest means of CFUs $(p<0.05)$ (Fig. 2).

Figure 3 shows representative SEM images after qualitative analysis from specimens at the

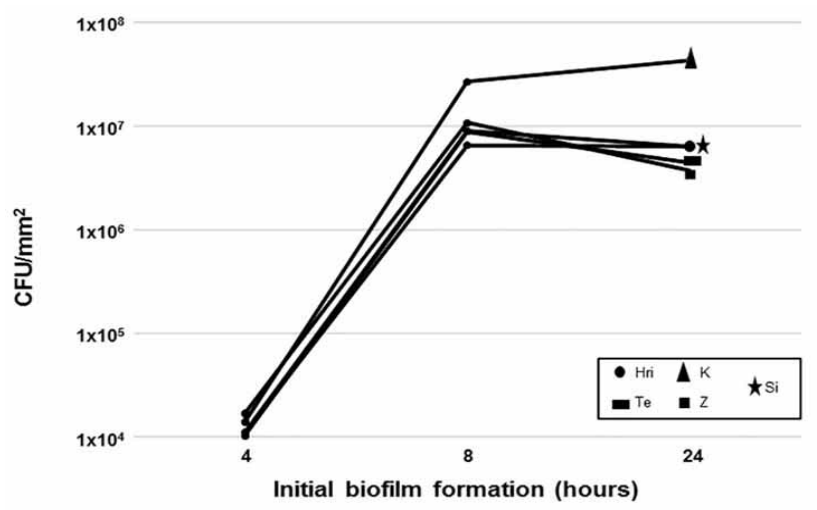

Fig. 1. Means of colony forming units (CFU/mm2) according to composites and biofilm formation (hours).

Hri: Enamel Plus HRI; K: KaloreTM; Si: FiltekTM Silorane; Te: Tetric EvoCeram® Bulk Fill; Z: FiltekTM Z250.

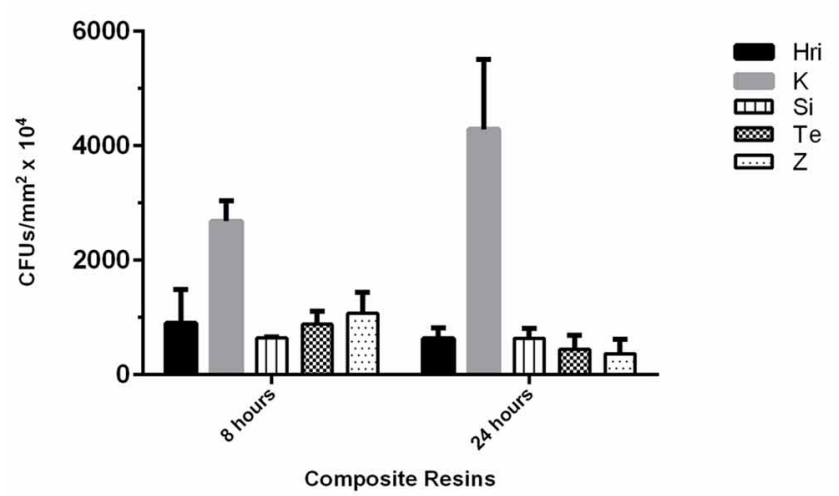

Fig. 2. Mean (standard deviation) upper limit of the confidence interval (95\%) of CFU/mm2 of composite resins at 8 and 24 hours. Hri: Enamel Plus HRI; K: KaloreTM; Si: FiltekTM Silorane; Te: Tetric EvoCeram® Bulk Fill; Z: FiltekTM Z250. 
SILVA, R. A. B.; NELSON-FILHO, P.; DE OLIVEIRA, K. M. H.; ROMUALDO, P. C.; GATÓN-HERNANDEZ, P.; AIRES, C. P. \& SILVA, L. A. B. Adhesion and initial colonization of streptococcus mutans is influenced by time and composition of different composites. Int. J. Odontostomat., 12(4):395-400, 2018.

Table II. Microbiological analysis of initial biofilms formed on different composites resins for 4, 8, or 24 hours (Mean $\pm \mathrm{SD} ; \mathrm{n}=3$ )

\begin{tabular}{cccc}
\hline Composite & \multicolumn{3}{c}{ Initial biofilm formation (CFU/mm2 x 104) } \\
\hline $\mathrm{Hri}$ & $1.09 \pm 0.22 \mathrm{Ba}$ & $897.06 \pm 593.37 \mathrm{Ab}$ & $632.51 \pm 183.94 \mathrm{Ab}$ \\
$\mathrm{K}$ & $1.40 \pm 0.29 \mathrm{Ba}$ & $2680.40 \pm 359.44 \mathrm{Aa}$ & $4286.31 \pm 1228.30 \mathrm{Aa}$ \\
$\mathrm{Si}$ & $1.10 \pm 0.11 \mathrm{Ba}$ & $649.81 \pm 13.49 \mathrm{Ab}$ & $639.14 \pm 172.67 \mathrm{Ab}$ \\
$\mathrm{Te}$ & $1.03 \pm 0.16 \mathrm{Ca}$ & $883.74 \pm 223.01 \mathrm{Ab}$ & $445.89 \pm 244.0 \mathrm{Bb}$ \\
$\mathrm{Z}$ & $1.69 \pm 0.50 \mathrm{Ca}$ & $1072.87 \pm 366.49 \mathrm{Aab}$ & $369.20 \pm 255.01 \mathrm{Bb}$ \\
\hline
\end{tabular}

Note: Within columns, lowercase letters represent comparisons among composites within each time of evaluation (equal letters indicate no significant difference [ $p>0.05]$ ). Within lines, uppercase letters represent comparisons among times of evaluation for each composite (different letters indicate significant difference [ $p<0.05])$. Hri: Enamel Plus HRI; K: KaloreTM; Si: FiltekTM Silorane; Te: Tetric EvoCeram ${ }^{\circledR}$ Bulk Fill; Z: FiltekTM Z250.
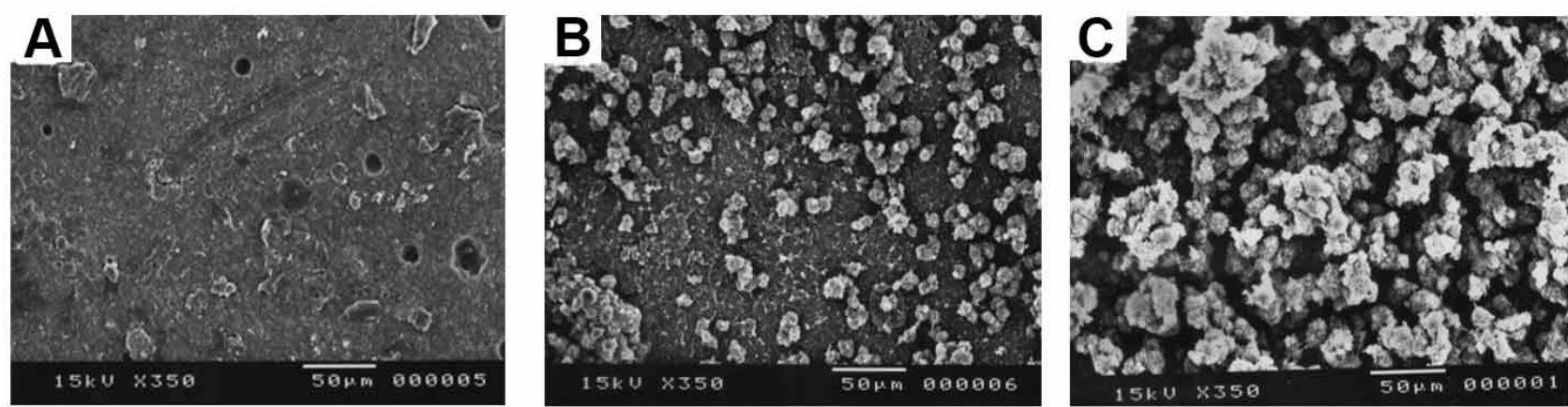

Fig. 3. Representative scanning electron micrographs showing progressive increase in the bacterial adhesion to the composite resins surfaces at 4 hours of incubation with S. mutans (A), 8 hours (B) and 24 hours (C).

different times $(4,8$, and 24 hours), showing a progressive increase in the amount of $S$. mutans on the surface of the composite resins according to time. No clear differences in the pattern of adhesion between the different composites were observed.

\section{DISCUSSION}

The reproduction of all in vivo conditions of the oral cavity for the analysis of biofilm formation is a very challenging process. For example, the use of intraoral splints for evaluation of different experimental materials is complex, time-consuming, and it's difficult to find a standardized methodology (Hahnel et al., 2014). Our model evaluated the adhesion of $S$. mutans at acid $\mathrm{pH}$, since that we used sucrose as a substrate in culture medium (Gregor et al.). However, pellicle acquired and other conditions that mediate in vivo bacterial adhesion were not contemplated. Nevertheless, the test conditions used allowed us to evaluate the adhesive properties of the restorative materials in a medium appropriated for bacterial growth. This condition allowed us to observe similar bacterial adhesiveness at first 4 hours of initial colonization for all groups, suggesting that initial colonization is not dependent of specimens surface (Barsotti et al., 1989).

The method for sterilization of the samples used in this study was by gamma irradiation. This is the method of choice, once it sterilizes without high temperature and pressure, or neither chemical products or gases. This method also does not affect the antibacterial properties of resin dental materials (Carvalho et al., 2009).

According to the manufacturers, all the composite resins evaluated in this study present improved polishing ability due to their composition of micro or nano particles. Specimens evaluated in this study were prepared with a Teflon matrix and a cellulose acetate strip to promote less bubble inclusion and regularization of the upper face. Pereira et al. (2011) evaluated the $S$. mutans adhesion on the surface of three composite resins following different finishing and polishing techniques. The authors showed that the group that received a matrix strip in contact with the resin surface and no additional finishing or polishing 
promoted the lowest bacterial adhesion on the surface of the micro-hybrid and nanofilled composites in the absence of human saliva.

In our study, it was observed that S. mutans' biofilm adhesion to composite resin surfaces is influenced by the dental material's composition and the period of time evaluated. In agreement with Buergers et al., the results of the present study showed that the evaluation of the scanning electron micrographs confirmed that $S$. mutans could adhere to the surface of different composite resins. According to our qualitative analysis, the evaluation of the scanning electron micrographs revealed no detectable differences in the pattern of adhesion between the groups evaluated during the different experimental periods.

Our results suggest that for $\mathrm{Hri}, \mathrm{K}$, and $\mathrm{Si}$ composites the bacterial adhesion increased with time. Some factors could affect bacterial adhesion, such as microstructure of the material including monomer composition, size, shape, and distribution of inorganic filler particles and physico-chemical characteristics like the roughness and hydrophobicity of the surface of the biomaterials (An \& Friedman, 1998; Teughels et al., 2006).

A high hydrophobicity may lead to lower absorption of hydrophilic molecules and improve the material's resistance to water and water-soluble species (Weinmann et al.). Schweikl et al. (2013) reported that the highest amounts of $S$. gordonii were detected on the hydrophilic surface of a glass ionomer cement, whereas a relatively small number of cells were found on the hydrophobic surfaces of a siloranebased composite (Filtek Silorane). Similarly, Buergers et al. found a lower quantity of adhering streptococci on the Filtek Silorane and methacrylate-based composites, such as Filtek Z250 and Tetric EvoCeram, which could be a result from their increased hydrophobicity. Since that colonization involves fundamental electrostatic, van der Waals, and hydrophobic interactions this is a complex process that remains poorly understood (An \& Friedman).

Our findings were in agreement with ClaroPereira et al. who found no statistically significant differences between FiltekTM Silorane and a methacrylate-based composite regarding bacterial adhesion. Therefore, these findings indicate that parameters other than hydrophobicity, like functionality of the surface, including charged groups, may be more relevant for the adhesion of microorganisms.
As already mentioned, the monomer could play an important role in relation to the bacterial adhesion. In our study, in contrast to Hri, $\mathrm{K}$ and Si results, duration of adhesion was not the same for Te and $Z$ groups. Matrices with Bis-GMA and TEGDMA tend to suffer more water sorption, however the amount of inorganic component present in the composite is inversely proportional to this phenomenon (Toledano et al., 2003). In the present study, the lower mean of CFU/mm² presented by the composite resins Te and $Z$ after 24 hours of incubation can be due the fact that both composites present the same matrix composition (BISGMA, BIS-EMA and UDMA).

The $\mathrm{K}$ composite presents monomers with a molecular weight almost double that of the Bis-GMA, which affords its low shrinkage (Yamasaki et al., 2013). However, for 8 and 24 hours of colonization, Kalore specimens significantly increased bacterial counting suggesting that polymerization shrinkage was not a factor to prevent bacterial adhesion. Furthermore, that composite presents a different monomer (DX-511 or Dupont monomer) which has an unknown influence on bacterial adhesion to biomaterials surfaces. Another specificity of the Kalore composite is that it has prepolymerized particles, which increases the filler content (69\% vol). Unfortunately, there are no studies in the literature evaluating the microbial adhesion to Kalore composite, that could allow for comparison with the results showed in the present study.

Further studies are necessary to determine not only the amount of bacterial adhesion to composite resins but also the surface properties like hydrophobicity, surface free energy, and electrical charge.

\section{CONCLUSIONS}

It was possible to conclude that:

- S. mutans biofilm adhesion to composite resin surfaces was influenced by the composition of resin composites in a time-dependent manner;

- All composite resins evaluated were susceptible to adhesion by streptococci. However, bacteria attachment was not sufficient to maintain $S$. mutans colonization on Tetric EvoCeram ${ }^{\circledR}$ Bulk Fill and FiltekTM Z250 composites; and

- Kalore composite presented the higher mean values for bacterial adhesion at 8 and 24 hours. 
SILVA, R. A. B.; NELSON-FILHO, P.; DE OLIVEIRA, K. M. H.; ROMUALDO, P. C.; GATÓN-HERNANDEZ, P.; AIRES, C. P. \& SILVA, L. A. B. La adhesión y la colonización inicial de Streptococcus mutans están asociadas al tiempo y la composición de diferentes compuestos. Int. J. Odontostomat., 12(4):395-400, 2018.

RESUMEN: El objetivo de este estudio fue evaluar la adhesión y la colonización inicial de $S$. mutans en la superficie de nuevas resinas compuestas durante tres períodos experimentales. Las biopelículas se formaron en muestras de Enamel Plus HRI (Hri), FiltekTM Silorane (Si), Tetric EvoCeram ${ }^{\circledR}$ Bulk Fill (Te), KaloreTM (K) y FiltekTM Z250 ( $Z$ ) ( $n=4 /$ período experimental). Después de 4,8 y 24 horas, las muestras se evaluaron para determinar los niveles de la unidad formadora de colonias bacterianas (UFC / $\mathrm{mm}^{2}$ ) y se escanearon por microscopía electrónica. Todas las superficies del material mostraron una susceptibilidad similar a la adhesión bacteriana a las 4 horas $(p>0,05)$. La cantidad de microorganismos en las biopelículas formadas aumentó a las 8 horas para todos los grupos $(p<0,05)$ y disminuyó a las 24 horas solo para los grupos Te y $Z(p<0,05)$. Después de 24 horas, el grupo $\mathrm{K}$ mostró mayores recuentos de microorganismos en comparación con los otros grupos. Todas las resinas compuestas evaluadas fueron susceptibles a la adhesión por estreptococos. Sin embargo, la unión de bacterias no fue suficiente para mantener la colonización de S. mutans en los compuestos Tetric EvoCeram ${ }^{\circledR}$ Bulk Fill y FiltekTM Z250. El compuesto $\mathrm{K}$ presentó los valores medios más altos para la adhesión bacteriana. Además, se observó que la composición de las resinas podría interferir con los mecanismos de colonización.

PALABRAS CLAVE: resinas compuestas, biofilm, Streptococcus mutans, microscopía electrónica.

\section{REFERENCES}

An, Y. H. \& Friedman, R. J. Concise review of mechanisms of bacterial adhesion to biomaterial surfaces. J. Biomed. Mater. Res., 43(3):338-48, 1998.

Barsotti, O.; Morrier, J. J.; Rocca, J. P.; Duprez, J. P. \& Dumont, J. Initial colonization of composite resins by Streptococcus mutans: the influence of polishing. Rev. Odontostomatol. (Paris), 18(3):213-20, 1989.

Bernardo, M.; Luis, H.; Martin, M. D.; Leroux, B. G.; Rue, T.; Leitão, J. \& DeRouen, T. A. Survival and reasons for failure of amalgam versus composite posterior restorations placed in a randomized clinical trial. J. Am. Dent. Assoc., 138(6):775-83, 2007.

Boaro, L. C.; Gonçalves, F.; Guimarães, T. C.; Ferracane, J. L.; Pfeifer, C. S. \& Braga, R. R. Sorption, solubility, shrinkage and mechanical properties of "low-shrinkage" commercial resin composites. Dent. Mater., 29(4):398-404, 2013.

Bowen, W. Wither or whither caries research? Caries Res., 33:1-3, 1999.

Buergers, R.; Schneider-Brachert, W.; Hahnel, S.; Rosentritt, M. \& Handel, G. Streptococcal adhesion to novel low-shrink siloranebased restorative. Dent. Mater., 25(2):269-75, 2009.

Carvalho, F. G.; Fucio, S. B.; Pascon, F. M.; Kantovitz, K. R.; CorrerSobrinho, L. \& Puppin-Rontani, R. M. Effect of gamma irradiation on fluoride release and antibacterial activity of resin dental materials. Braz. Dent. J., 20(2):122-6, 2009.

Claro-Pereira, D.; Sampaio-Maia, B.; Ferreira, C.; Rodrigues, A.; Melo, L. F. \& Vasconcelos, M. R. In situ evaluation of a new silorane-based composite resin's bioadhesion properties. Dent. Mater., 27(12):1238-45, 2011.

Delaviz, Y.; Finer, Y. \& Santerre, J. P. Biodegradation of resin composites and adhesives by oral bacteria and saliva: a rationale for new material designs that consider the clinical environment and treatment challenges. Dent. Mater., 30(1):16-32, 2014.

Ferracane, J. L. Resin composite--state of the art. Dent. Mater., 27(1):29-38, 2011

Filoche, S.; Wong, L. \& Sissons, C. H. Oral biofilms: emerging concepts in microbial ecology. J. Dent. Res., 89(1):8-18, 2010.

Gao, B. T.; Lin, H.; Zheng, G.; Xu, Y. X. \& Yang, J. L. Comparison between a silorane-based composite and methacrylate-based composites: shrinkage characteristics, thermal properties, gel point and vitrification point. Dent. Mater. J., 31(1):76-85, 2012.

Goldberg, M. In vitro and in vivo studies on the toxicity of dental resin components: a review. Clin. Oral Investig., 12(1):1-8, 2008.

Gregor, L.; Bortolotto, T.; Feilzer, A. J. \& Krejci, I. Shrinkage kinetics of a methacrylate- and a silorane-based resin composite: effect on marginal integrity. J. Adhes. Dent., 15(3):245-50, 2013.

Hahnel, S.; Wastl, D. S.; Schneider-Feyrer, S.; Giessibl, F. J.; Brambilla, E.; Cazzaniga, G. \& Ionescu, A. Streptococcus mutans biofilm formation and release of fluoride from experimental resinbased composites depending on surface treatment and S-PRG filler particle fraction. J. Adhes. Dent., 16(4):313-21, 2014.

Pereira, C. A.; Eskelson, E.; Cavalli, V.; Liporoni, P. C.; Jorge, A. O. \& do Rego, M. A. Streptococcus mutans biofilm adhesion on composite resin surfaces after different finishing and polishing techniques. Oper. Dent., 36(3):311-7, 2011.

Schweikl, H.; Hiller, K. A.; Carl, U.; Schweiger, R.; Eidt, A.; Ruhl, S.; Müller, R. \& Schmalz, G. Salivary protein adsorption and Streptococccus gordonii adhesion to dental material surfaces. Dent. Mater., 29(10):1080-9, 2013.

Spencer, P.; Ye, Q.; Misra, A.; Goncalves, S. E. \& Laurence, J. S. Proteins, pathogens, and failure at the composite-tooth interface. J. Dent. Res., 93(12):1243-9, 2014.

Teughels, W.; Van Assche, N.; Sliepen, I. \& Quirynen, M. Effect of material characteristics and/or surface topography on biofilm development. Clin. Oral Implants Res., 17 Suppl. 2:68-81, 2006.

Toledano, M.; Osorio, R.; Osorio, E.; Fuentes, V.; Prati, C. \& GarciaGodoy, F. Sorption and solubility of resin-based restorative dental materials. J. Dent., 31(1):43-50, 2003.

Weinmann, W.; Thalacker, C. \& Guggenberger, R. Siloranes in dental composites. Dent. Mater., 21(1):68-74, 2005.

Yamasaki, L. C.; De Vito Moraes, A. G.; Barros, M.; Lewis, S.; Francci, C.; Stansbury, J. W. \& Pfeifer, C. S. Polymerization development of "low-shrink" resin composites: Reaction kinetics, polymerization stress and quality of network. Dent. Mater., 29(9):e169-79, 2013.

Corresponding author:

Priscilla C. Romualdo

Department of Pediatric Dentistry

School of Dentistry of Ribeirão Preto

University of São Paulo

Av. Do Café s/n

Monte Alegre, 14090-904

Ribeirão Preto, SP

BRAZIL

Email: priscilla.romualdo@usp.br

Received: 29-05-2018

Accepted: 06-08-2018 